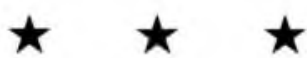

\section{News from the Field}

\section{Acquisitions}

- Boston College has acquired the papers of Gerard Manley Hopkins, which are particularly valuable because Hopkins destroyed so much of his writing, believing it to be unworthy of his decision to become a Jesuit. Included are the poet's generously annotated Bible, which illuminates Hopkins's conversion to Catholicism at the age of 22 , and a letter written during his prep school years, describing how he was whipped and nearly expelled from school for "a most trifling ludicrous little thing." Also included are 75 books and family materials from his parents' library.

- Boston University has been given the papers of singer-satirist Anna Russell for the Twentieth Century Archives in its Department of Special Collections.

- The Popular Culture Library at Bowling Green State University has acquired more than 400 linear feet of original scripts for television soap operas, production documentation, and commercial materials from the Proctor and Gamble Company, which virtually created this genre of popular entertainment. The scripts date from as early as 1954 and include long, consecutive runs of shows such as "Edge of Night," "Another World," "Search for Tomorrow," and "The Guiding Light." The gift also includes shorter runs of scripts from other daytime serials-"For Richer, For Poorer," "Young Doctor Malone," "The Loretta Young Show," and the critically acclaimed miniseries "From These Roots." With financial assistance from Proctor and Gamble, the collection will be microfilmed. The Popular Culture Library staff has organized the scripts and related materials by series title and arranged them chronologically to make them more accessible to researchers.

- Columbia University has received the archives of avant-garde publisher Lita Hornick, founder of Kulchur Press and the Kulchur Foundation. To celebrate the gift, the library has mounted a major exhibit of manuscripts, portfolios, editorial records, and other materials called "Kulchur Queen and Kulchur Books: Lita Hornick and the Poets She Published." It will be on view in the Kempner Exhibition Room of the Rare Book and Manuscript Library through June 28.
- The Hoover Institution has opened a library and archival acquisitions office in Warsaw, Poland, to help expand its documentation of the sweeping changes taking place throughout Eastern Europe and the USSR. The new office will be directed by Maciej Siekierski, deputy curator of the Hoover's East European Collection. Siekierski holds a doctorate in Russian and East European history from the University of California-Berkeley as well as an MLS.

- Louisiana Tech University has opened a major research collection related to the history and development of the timber industry as well as management and conservation of Louisiana forests in the 20th century. The Forestry Archives contain several collections of primary materials, including office files, correspondence, photographs, and research reports. They are available at the Prescott Memorial Library in Ruston, Louisiana.

- Syracuse University's George Arents Research Library became the principal repository in the United States of original Albert Schweitzer papers with its recent acquisition of a major collection of correspondence between Schweitzer and his wife Helene.

- The University of California, Santa Cruz has been given the working library of Dickens scholar Ada B. Nisbet, a distinguished Dickens scholar who taught and did research on Dickens and Victorian literature until her retirement at UCLA in 1974. The collection includes rare first editions and trade editions of Dickens's works, as well as several hundred books about Dickens and the Victorian era, original watercolor and engraved illustrations, and engraved plates. Rare and valuable items include a serial set of David Copperfield once owned by movie magnate David O. Selznick, who produced the classic film version.

- The University of Iowa in Iowa City has completed its collection of all the editions of Leaves of Grass, thanks to three recent gifts from the Friends of the University of Iowa Libraries, making Iowa one of only a handful of libraries that own all the versions of Whitman's evolving book of poems. The latest acquisition is a copy of the 1856 edition, important for its revelation of Emerson's influence on Whitman and for the collection in the back of reviews of the first edition of Leaves. This selection of "Leaves-Droppings" includes anonymous re- 
views written by Whitman himself and two very negative reviews, one by an unappreciative critic who asserted that Whitman was "as unacquainted with art, as a hog is with mathematics."

- The University of Miami Library has acquired a John Dos Passos collection, consisting of the research files of Virginia Spencer Carr, author of Dos Passos: A Life (Doubleday, 1984). Included in the research materials are correspondence, photographs, and interviews with several contemporaries and family members of John Dos Passos.

- The University of Notre Dame Libraries have received two collections, one of sea charts and one of maps of Ireland, from Mr. and Mrs. Thomas C. McGrath of Juno Beach, Florida. The oldest map in the collection, made in 1567 by Benedetto Bordone, is believed to be the earliest printed map depicting Ireland alone. Most of the 11 sea charts date from the 17 th century. One, printed by L. Wagenhaer, is the first printed chart showing the coast of Ireland alone.

\section{Grants}

- American Institute of Physics in New York City has received $\$ 100,000$ from the National Historical Publications and Records Commission. The funds are for the second phase of a project to analyze the records created by multi-institutional teams doing research in physics, identify and test alternative approaches to preserving team research records of historical significance and enhancing their potential for research use, and develop policy recommendations and programs to deal with the present and future documentation of these teams and their work.

- Georgia State University's William R. Pullen Library recently received a $\$ 10,000$ endowment grant from the Atlanta Foundation, to be counted toward the matching portion of a $\$ 400,000 \mathrm{NEH}$ challenge grant. The grant was awarded to support GSU's development of library collections in the departments of English, foreign languages, history, and philosophy, both through immediate acquisitions and through building an endowment.

- Haverford College's Magill Library is one of 16 Philadelphia-area research libraries chosen to participate in "Initiative for the 1990 's, "funded by a \$2.77 million grant from the Pew Charitable Trusts. When the 22-month project is completed Magill Library will have added 63 Quaker manuscript collection records to OCLC and RLIN. Haverford's share of the grant will underwrite hiring additional professional staff to help with the project and purchasing a computer, a printer, and software.
- Indiama University has been awarded $\$ 501,318$ in HEA II-C funds to continue retrospective conversion of manual bibliographic records for printed music, for entry into OCLC and RLIN. Cornell University, Eastman School of Music, Harvard University, and the University of California, Berkeley, are cooperative partners.

- The Jewish Theological Seminary has received an HEA II-C grant of $\$ 90,538$ to catalog, conserve, microfilm, and improve scholarly access to an important fragile body of primary sources of Judaic and Hebraic broadsides, spanning 500 years of history and ranging from poetry to politics. Bibliographic data will be entered into RLIN.

- The Municipal Archives, a division of the New York City Department of Records and Information Services, has received $\$ 25,000$ from the Andy Warhol Foundation for the Visual Arts for preservation of 720,000 photographs depicting every house and building in the five boroughs of New York City. The pictures were taken by Works Project Administration photographers from 1939 to $194 \mathrm{l}$ for the city's Department of Taxes. The total cost of restoring these images is $\$ 200,000$, of which $\$ 85,000$ has so far been received in grant funds.

- Ohio State University in Columbus has received an HEA II-C award of $\$ 87,143$ to preserve and provide online bibliographic access to its extensive collections of historical (15th through 20 th century) theatrical documents in microform in its Lawrence and Lee Theatre Research Institute Library.

- The Philadelphia Area Consortium of Special Collections Libraries has received agrant of $\$ 147,876$ from the National Historical Publications and Records Commission for a three-year project to make additions to the Library of Congress Name Authority File.

- Smithsonian Institution Libraries in Washington, D.C., received $\$ 15,000$ from the James Smithson Society to help support an exhibition, "Nusantara: Lands and Peoples of Indonesia," April-November 1991. The exhibition is part of the International Festival of Indonesia.

- Southwestern College Memorial Library, Winfield, Kansas, has received a \$2,000 Interlibrary Loan Development Program grant from the Kansas Library Network Board. The grant will make available to Kansas libraries books and videos that deal with rural nursing.

- University of Arizona at Tucson has received an HEA II-C grant of $\$ 70,803$ to create original cataloging records for over 1,000 titles, enhance 2,120 existing records, and convert cataloged titles to machine-readable MARC records, thus improving access to the Latin American and Hispanic cartographic materials in the Map Collection. 
- University of Notre Dame Archives and University Libraries have been awarded a $\$ 48,706$ federal grant to create machine-readable bibliographic records of about 500 collections. The records will be entered into OCLC. The collections include the personal papers of Civil War General William Tecumseh Sherman, Postmaster General Frank C. Walker, philosopher Orestes Brownson, early Notre Dame scientists Albert Zahm and Julius Nieuwland, and former Notre Dame president Theodore M. Hesburgh; manuscript collections of poet Raymond Ellsworth Larrson, journalist John T. Frederick, artist Eric Gill, and missionary priest Nicholas Louis Sifferath; and the 1567-1897 archives of the Diocese of Louisiana and the Floridas.

- University of California, Berkeley, has won an HEA II-C grant of $\$ 311,533$ to complete conversion of over 210,000 records of research materials in the Bancroft Library and enter them into OCLC and RLIN. The Bancroft Library has two collections of internationally recognized distinction: Western Americana including materials on Mexico and Central America, and the Rare Books Collection, with extensive manuscript holdings and important printed collections in numerous fields. UCB will also receive $\$ 122,465$ to catalog and conserve rubbings of 2,700 Chinese inscriptions made mostly in stone. These inscriptions commemorate events and preserve texts of philosophical and religious canons and provide valuable information for studying Chinese civilization.

- University of California, Los Angeles, has been awarded $\$ 214,893$ in HEA II-C funds for a joint project with the University of California, Berkeley, to catalog and create machine-readable bibliographic records for maps of California. The records will be available through OCLC and RLIN.

- University of California, Riverside has been awarded $\$ 138,302$ in HEA II-C funds to continue to create machine-readable catalog records for units 1-48 of the English Books: Series I, 1475-1640. The records will be added to the English Short Title catalog (ESTC).

- University of Chicagohas received $\$ 100,060$ in HEA II-C funds to complete a project begun in 1989 to acquire and preserve books on classical and ancient India and Great Britain, none of which is held by a research library in the United States.

- University of Idaho has received an HEA II-C grant of $\$ 33,985$ to complete the arrangement and description of the records of north Idaho's Day Mines Group, prepare a comprehensive guide to the collection, and make a report on the historical appraisal of industry records for publication in the archival literature.

- The Chester Fritz Library at the University of North Dakota in Grand Forks has been named the 67th Patent and Trademark Depository Li- brary in the United States-and the only one in the upper central Midwest-thanks to a grant of $\$ 80,000$ from the $3 \mathrm{M}$ Company. The gift is providing half of the startup costs, including purchase of a 26-year backfile of patent information on CDROM and the equipment to make the information accessible. The new depository will be open for patent and trademark research by June 1 .

- The Regents of the University of Michigan, Bentley Historical Library, Ann Arbor, have received a conditional grant of $\$ 19,139$ from the National Historical Publications and Records Commission for the first year of the university's project to examine the potential of electronic conferences to document the intellectual and cultural life of institutions of higher learning.

\section{Call for agenda items for the ACRL annual membership meeting}

The ACRL annual membership meeting will be held on Monday, July 1, 1991, 2:00-2:30 p.m. in Atlanta. ACRL President Barbara J. Ford would like to hear from members about their suggestions for agenda items. Send suggestions by June 1, 1991, to Ford at Trinity University Libraries, 715 Stadium Drive, San Antonio, TX 78212, or BITNET: BFORD @ TRINITY. The ACRL President's Program on information literacy immediately follows the business meeting

\section{Disabilities discussion group to meet}

"Service Policies" will be the topic when the Academic Librarians Assisting the Disabled Discussion Group meets in Atlanta on Monday, July 1, 9:30-11:00 a.m. Anyone who is interested may attend. The group, part of the Libraries Serving Special Populations Section of the Association of Specialized and Cooperative Library Agencies (ASCLA), is particularly for academic librarians whose primary responsibilities are not services for users with disabilities. It provides opportunities to share information and experiences with other nonspecialists.-Jim Neeley, Chair 


\section{News notes}

- The American Theological Association will hold its annual conference in Toronto, Ontario, Canada, on June 19-22, 1991. The meetings will be on the campus of the University of Toronto. Hosts are Trinity College and the Toronto School of Theology.

- The Association of Christian Librarians will hold its 35th annual conference June 11-14, 1991, at the Eastern Pentecostal Bible College in Peterborough, Ontario, Canada.

- Boston University is celebrating the centennial of Alexander Kipnis's birth with an exhibit of photos, posters, and programs from his performances around the world. The exhibit is among several events in the United States honoring the Russian-born bass who performed more than 80 operatic roles during a career that began in Berlin in 1913 and ended in the United States in the early 1950s. A special preview of the exhibit on March 15 was hosted by Howard Gotlieb, director of Special Collections at Mugar Memorial Library. Among the scheduled speakers were the singer's son, the distinguished harpsichordist Igor Kipnis, and Phyllis Curtin, soprano and dean of Boston University's School for the Arts. The exhibit will continue through August 1991.

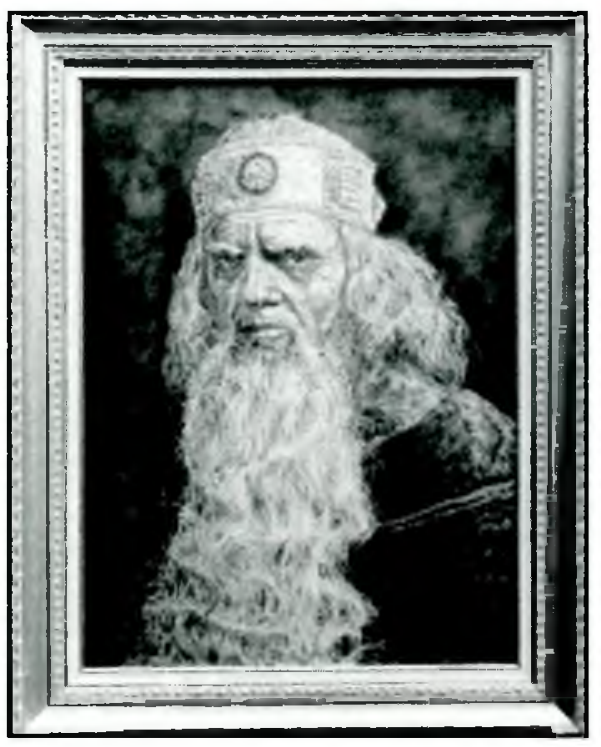

A painting by CARA of Kipnis as King Arkel. Photo credit: Boston University Photo Service
- Duke University has received $\$ 2.5$ million from Ruth Lilly for its East Campus Library, to be renamed the Lilly Library, in honor of the donor's nieces and their families, all of whom have either graduated from, or are presently attending, Duke. The gift was celebrated with a reception in honor of Ruth Lilly in November. Also in November, Duke's new Library Advisory Board met for the first time. The 19-member board, invited to serve by Duke president $\mathrm{H}$. Keith Brodie, has two missions: to assist in strengthening the financial position of the library and to channel to the provost recommendations to improve the library at Duke.

- At Harvard University, three off-color Mozart canon texts that were suppressed when the music was first published in 1804, have been rediscovered in two volumes recently acquired by the Eda Kuhn Loeb Music Library. Librarian Michael Ochs announced the find on February 4 at the International Mozart Congress 1991 in Salzburg, Austria. The texts have been sought by scholars for more than a century. Their existence was known from a letter by the composer's widow in which she called them "unruly." The three canons with their newly restored scatological texts will be recorded later this year on the Philips label as part of a project to issue all of Mozart's works on compact disc.

- The Historical Society of Pennsylvania will publish a new Guide to the Manuscript Collections this month, according to the Society's president, Susan Stitt. The guide will contain numbered summary descriptions of 2,170 collections, comprising some 12 million documents preserved in the Society's Manuscripts and Collections Department at 1300 Locust Street, Philadelphia. The guide has been in progress for 13 years at the Society, America's largest independent research center for American and Pennsylvania history. It will update researchers on the collections the Society has received since 1949 , when its previous guide was published. The collections date from 1630 and include unpublished articles, personal and business papers, letters, diaries, financial records, autograph books, and accounts and minutes of organizations.

- New Mexico State University brokeground last December for a new \$11.1 million library. Inspired by a photograph of the 1928 groundbreaking ceremony for the campus' first library, library director Charles Townley persuaded New Mexico State University president James Halligan to do the honors for the ceremony with team and plow.

- New York University has received a \$1.1 million endowment to support expansion of library collections and services, thanks to a bequest from the estate of Mr. and Mrs. John E. Raasch. Raasch, a 1917 graduate of NYU's School of Commerce, was chairman of the Grand Union Company and John Wanamaker Department Stores until his 
death in 1972. Throughout his life, he was an active member of the NYU alumni community.

- Pace University is beginning to automate its libraries in New York and Westchester Countywith the installation of an online catalog and barcoding of some 850,000 volumes. The university signed a contract for the purchase and installation of the Innovacq/Innopac Automated Integrated Library System.

- The University of Iowa Libraries in Iowa City have completed a major reorganization. The most significant change has been to group together staff, collections, and services that reflect the broad organization of the university: humanities, social sciences, and sciences. Within each of the discipline divisions, librarians with responsibilities for reference and user education services, collection development and management, and cataloging are brought together. Support staff whose work assignments fall within the discipline divisions also are part of this new team structure. Each discipline division has a coordinator who will facilitate activities among the various staff. The goal of the reorganization is to enhance services to faculty and students through an affiliation of librarians with subject expertise and responsibilities. There remains an international cluster within the library organization that includes those librarians who have responsibility for collections and services specific to a geographic region. In the new organi-

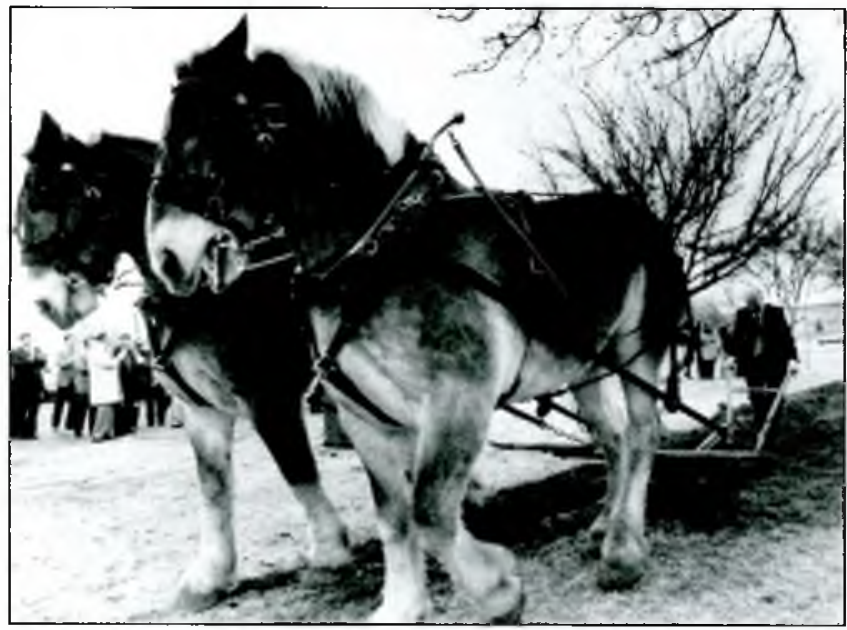

Groundbreaking for New Mexico State University Library zation, Acquisitions Department staff report to the Director of Collection Development and Management, as do the Preservation Librarian, a new position, and the University Conservator.

- The University of Miami Library, Archives and Special Collections Department (Coral Gables, Florida), has completed a register to its Theodore Spicer-Simson Collection, which includes the papers and medallic portraits of Theodore Spicer-Simson, a distinguished sculptor and medallic portrait artist.

- A task force at the University of North Carolina, Chapel Hill, is studying the library to identify ways to slow fiscal erosion of its collections and operations. The nine-member panel was appointed after the Administrative Board of the Academic Affairs Library approved a 1990-1991 book budget of $\$ 608,000-\$ 33,000$ less than the library's book budget 20 years ago. UNC Chancellor Paul Hardin appointed the task force to determine the condition of campus libraries and recommend improvements.

- The University of Notre Dame has established a new faculty award for members of its library faculty. The Rev. Paul J. Foik, C.S.C., Award will be given annually to a library faculty member who has contributed significantly to library service to the Notre Dame community or to the library profession through personal scholarship or involvement in professional associations. Nominations for the award, which will include a $\$ 1,000$ honorarium, will be solicited from the entire university community and forwarded to a selection committee composed of representatives of the teaching and research faculty, the library faculty, the Graduate Student Union, and the undergraduate student body. Father Foik, a Notre Dame alumnus, organized and professionalized the Notre Dame library during his tenure as librarian 1912-24. An active organizer of library education programs at Notre Dame and elsewhere, he is considered the leading Catholic library figure of his time. 